\title{
Electronic learning in the German science project 'Nawi-Interaktiv'
}

\author{
Dr Claas Wegner ${ }^{1}$, Dr Wiebke Homann ${ }^{2, *}$ and Friederike Strehlke ${ }^{3}$ \\ ${ }^{1}$ Department for Didactics of Biology, Bielefeld University, Bielefeld, Germany \\ ${ }^{2}$ Department 'Bielefeld School of Education', Bielefeld University, Bielefeld, Germany \\ ${ }^{3}$ Department for Didactics of Biology, Bielefeld University, Bielefeld, Germany \\ For correspondence: Friederike.Strehlke@Uni-Bielefeld.de
}

\begin{abstract}
:
The German science project 'NAWI-Interaktiv' is an example of innovative use of E-Learning and new media education. Since 2009, the learning platform provides learners and teachers with high-quality learning tools, teaching material, useful information and E-learning programs for free. This is to raise the pupils' motivation to learn about scientific phenomena, on the one hand, and also provides teachers with future-oriented course material for the fields of science education. 'NAWI-Interaktiv' aims at advancing the pupils' scientific literacy and new media education and it improves the quality of science teaching as it uses media and technology as instruments to improve learning and also as objects to learn about.
\end{abstract}

Keywords: E-Learning, Science Project, Innovative Platform, Teaching Material

\section{Introduction}

The PISA 2000 study shows relatively poor results for the German students' scientific literacy (Prenzel et al. 2001). Although the PISA 2009 study reports these competences improved, the development of methods to support student performance is demanded in the German education system (Rönnebeck et al. 2010). In the light of this evidence, electronic learning and teaching is often discussed to be a useful strategy. New media allows for new didactic potential and innovative aspects of teaching and learning. Besides, computer-aided learning is fun for children because of the system's immediate response, for example in quizzes or games and the integration of both visual and auditory elements in tasks. This appeals to all kinds of learners and their individual learning styles.

Appropriate technological resources, Internet applications like blogs or wikis, learning software and other E-Learning scenarios support learning and teaching processes immensely because of their high motivational factor for young people. Learning software and programs are designed to achieve learning goals for certain subjects (Klimsa \& Issing 2002). However, many teachers experience innovations in the media and technology sector and working with those in their lessons as a challenge. Not only do teachers need to know how to use the new media themselves but they also have to develop their technological education in ways that are stimulating and useful for pupils. It can be very complicated and time-consuming for teachers to find non-commercial educational programs on the Internet which are also suitable for direct use in science classes. It is certainly possible to design such tools for your students yourself; still, this takes up a considerable amount of time, effort and skill.

This article presents Bielefeld University's science project 'NAWI-Interaktiv' as an example of an innovative learning platform. It provides interested users with high-quality science learning tools and materials aiming at advancing learning and teaching and it supports new media education. First, however, the article explains what new media education in the fields of Didactics of Biology means and what media education in science lessons aims at. 


\section{New Media Education in the Fields of Didactics of Biology}

Generally, new media education can be approached from two perspectives. On the one hand, it can be used as an instrument to enhance learning in general and to improve the students' performance in specific areas. On the other hand, computers and the Internet serve as objects on their own to learn about. It is important for pupils to adopt a critical attitude towards the media and to learn how to use them in a responsible, mature way. In order to both expand your students' media skills and their scientific literacy, you need to implement appropriate methodological-didactical approaches and tasks.

Biology, for example, is a subject frequently using experiments to teach about nature and living organisms. With the help of computers and learning software, pupils can experience biological contents in a visual way. Since those learning programs offer interactive tasks, the pupils' autonomy level and self-directed learning is supported as well. In comparison to using print media, working with the Internet offers huge advantages in the area of science when it comes to the timeliness and the graphic qualities of data (Bickel-Sandkötter 2003). For example, videos of experiments that cannot be conducted in school due to safety reasons or a lack of time and material can be shown on computers in biology lessons. In the field of Didactics of Biology experts expect this to increase the students' scientific knowledge and their motivation to a high degree (Prenzel et al. 2000).

Since the Internet is a useful instrument when it comes to scientific research, it is essential for students to learn how to work with online research engines and how to reflect on the credibility of the presented sources critically (Meister \& Sander 1999). However, it has to be kept in mind that using new media only improves your pupils' skills and competence if you use didactically appropriate software, material and tasks.

\section{The Project NAWI-Interaktiv}

Dr Wiebke Homann and Dr Claas Wegner from Bielefeld University's Department of Didactics of Biology established the learning platform 'NAWI-Interaktiv' in 2009. It provides learners and teachers with high-quality learning tools, useful information and E-learning programs for free. All materials available on the platform have been developed with the help of university students

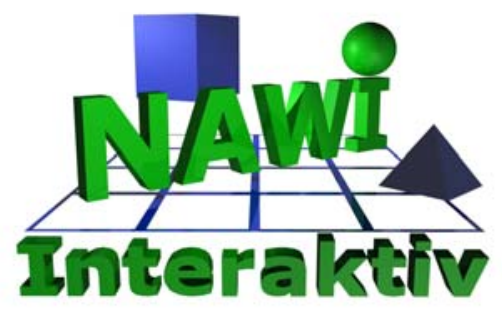
planning to become biology teachers at secondary schools. Hence, the university students designing the materials and tools improve both their media skills as well as their pedagogical content knowledge (Homann et al. 2011).

As the materials are didactically prepared and designed for direct use, the platform saves teachers a lot of time and helps them to improve their lessons' quality. Schools benefit from employing those non-commercial materials and they can integrate them into their curricula directly while the pupils profit from the wide range of motivating learning materials. Further, pupils get the chance to improve their media competences through exploring the website and its interactive learning tools. Also, they foster their content knowledge in the fields of biology and science. Hence, the project uses media and technology in a responsible way for two reasons, namely as an instrument to improve learning in general and also as an object on its own to learn about. The project's name 'NAWI-Interaktiv' describes learning about natural science (German: NAturWIssenschaften) in an interactive way. 


\section{The Project's Platform}

The project's website www.Nawi-Interaktiv.com contains a variety of different informative and educational elements addressing the needs and interests of secondary school students, their parents, university students and teachers. However, the platform is especially useful for science teachers since the topics dealt with are included in the syllabi of secondary schools. Further additional material, such as worksheets, didactical notes and lesson plans, is also available for free. This makes the preparation and planning of interesting lessons much easier for teachers.

The different learning materials are structured in a clear way since they are designed in order to be used directly in the classroom. The goal of these materials is to support and optimize the pupils' learning processes and to raise the children's and young adults' interest in science in general. A table of contents presents the different topics as an overview of the different learning tools also shows whether the course material is suitable for secondary level I or II. There are materials to be found regarding ecology, plants, nutrition and cell biology and also other topics. You also have the chance to choose between tools according to their multimedia-representation, such as learning programs, virtual tours or films. Generally, the project's website helps pupils to acquire scientific knowledge and teachers to simplify and organize the preparation and realization of their lessons.

\section{Conclusion}

Since the use of new media in the fields of science education will gain ongoing importance in the future, teachers and future teachers have to be introduced to E-Learning scenarios and their benefits for education as soon as possible. It has shown to be very motivational and effective for both students and teachers to work with computers and E-Learning scenarios in school. Also, users have the opportunity to use this very E-Learning platform whenever they prefer to via the Internet, this means they can also explore biological topics at home through interactive, playful tasks. This way of selfdirected learning decreases the threat of over- or under-challenging situations for pupils which often lead to a loss of motivation. Besides serving as a tool to improve the students' learning processes, the platform helps university students to learn about dealing with a new set of media and technology themselves. They improve their media skills and are competent using these in their professional life.

Another beneficial element of this E-Learning platform is that it can be used at any time, thus teachers, pupils and parents have unlimited access to it. The huge repertoire of materials and video clips is improved and extended constantly. The project itself offers an innovative technology-based program and effective way of improving teaching and learning techniques with the help of new media. This kind of learning environment has practical value for all sorts of education and is recommended to be used in universities and schools more often.

\section{References}

Homann, W., Wegner, C. \& N. Grotjohann (2011): “E-Learning im Unterricht”. merz - medien und erziehung Zeitschrift für Medienpädagogik, 55(1), 81 - 83.

Klimsa, P., \& Issing, L. J. (2002): Information und Lernen mit Multimedia und Internet. Lehrbuch für Studium und Praxis. Weinheim: Verlagsgruppe Beltz.

Meister, D. M., \& Sander, U. (1999): Multimedia. Chancen für die Schule. Berlin: Luchterhand.

Prenzel, M. et al. (2000): Didaktisch optimierter Einsatz Neuer Medien: Entwicklung von computergestützten Unterrichtskonzepten für die naturwissenschaftlichen Fächer. In: Leutner, D.; Brünken, R.: Neue Medien im Unterricht, Aus- und Weiterbildung: Aktuelle Ergebnisse empirischer pädagogischer Forschung. Münster: Waxmann.

Prenzel, M., Rost, J., Senkbeil, M., Häußler, P. \& Klopp, A. (2001). Naturwissenschaftliche Grundbildung: Testkonzeption und Ergebnisse. In: Baumert, J., Klieme, E., Neubrand, M., Prenzel, M., Schiefele, U., Schneider, W., Stanat, P., Tillmann K.-J. \& Weiß M. (Hg.): PISA 2000. Basiskompetenzen von Schülerinnen und Schülern im internationalen Vergleich (S. 192- 250). Opladen: Leske + Budrich.

Rönnebeck, S., Schöps, K., Prenzel, M., Mildner, D. \& Hochweber, J. (2010). Naturwissenschaftliche Kompetenz von Pisa 2006 bis Pisa 2009. In: E.Klieme, C. Artelt, J. Hartig, N. Jude, O. Köller, M. Prenzel et al. (Hrsg.): PISA 2009. Bilanz nach einem Jahrzehnt. Münster: Waxmann. 177-198. 